$$
\begin{aligned}
& A T-(40-1)-4485-1 \\
& \text { TID-2658I }
\end{aligned}
$$

\title{
PROGRESS REPORT
}

TITLE: Artificial Heart Controls Support

PRINCIPAL INVESTIGATOR: F. M. Donovan, Jr., Ph.D.

\author{
BIOMEDICAL ENGINEERING
}

THE UNIVERSITIES CENTER - JACKSON

1855 EASTOVER DRIVE

JACKSON, MISSISSIPPI 39211

May 1, 1974$$
\text { ThOTICE }
$$

This report was prepared as an account of work sponsored by the United States Government. Neither the United States nor the United States Atomic Energy Cominission, nor any of their employees, nor any of their contractors, subcontractors, or ther employees, makes any warranty, express or implied, or assumes any legal liability or responsiblity for the accuracy, completeness or usefulness of any information, apparatus, product or process disclosed, or represents that its use would not infringe privately owned rights.

\section{F 2938 \\ WA 231974}

DISTRIBUTION OF THIS DOCUMENT IS UNLIMITED 


\section{DISCLAIMER}

This report was prepared as an account of work sponsored by an agency of the United States Government. Neither the United States Government nor any agency Thereof, nor any of their employees, makes any warranty, express or implied, or assumes any legal liability or responsibility for the accuracy, completeness, or usefulness of any information, apparatus, product, or process disclosed, or represents that its use would not infringe privately owned rights. Reference herein to any specific commercial product, process, or service by trade name, trademark, manufacturer, or otherwise does not necessarily constitute or imply its endorsement, recommendation, or favoring by the United States Government or any agency thereof. The views and opinions of authors expressed herein do not necessarily state or reflect those of the United States Government or any agency thereof. 


\section{DISCLAIMER}

Portions of this document may be illegible in electronic image products. Images are produced from the best available original document. 
Most of the activity under this contract, up to May 1, 1974, has been directed to an analysis of the cardiac output sufficiency and predicted impairment in the United States adult population using the nuclear powered artificial heart. Cardiac output is a function of metabolic energy utilization determined by the basal metabolic rate, which is a function of height, weight, age, and sex, and the metabolic energy required to support physical activity, which is a function of the activity itself, and the weight of the individual. The distribution of basal cardiac output in the adult population in the United States was determined using the age, height, weight, and sex distribution of the population from a number of sources including the 1970 Census. Once this was done, the cardiac reserve, that is the difference between the maximum cardiac output and the basal cardiac output, was determined for the various groups under conditions of no anemia, moderate anemia, and severe anemia. Moderate anemia refers to the condition in which the basal cardiac output is increased by $50 \%$, Severe anemia refers to the condition in which basal cardiac output is increased by $100 \%$. The various groups were then classified as Normal, Class I (no symptoms with ordinary activity), Class II (no symptoms at rest, symptoms with ordinary activity), Class III (comfortable at rest, symptoms with less than ordinary effort), Class IV (symptoms at rest), Class D (unable to support basal metabolic rate). Class I, II, III, and IV are in accordance with the New York Heart Association classification of cardiac patients. This analysis was carried out with a maximum cardiac output capabilities of 12,9 , and 6 $1 /$ min. The results of these investigations are summarized in Fig. 1. Note that with maximum output capability of $12 \mathrm{l} / \mathrm{min}$. and no anemia, practically any member of the adult United States population could be supported with 
practically no impairment to their activities. However as anemia progresses to moderate and severe, the bulk of the population shifts from normal and Class I to Class II and III, and then to Class III and IV. As the maximum cardiac output capability decreases, from 12 to 9 to $61 / \mathrm{min}$. with no anemia, the bulk of the population again shifts from Normal and Class I, to Class I and II and then to Class III and IV. However, with even moderate anemia a maximum output of $61 / \mathrm{min}$. is insufficient to support 1 ife and a maximum output of $9 \mathrm{l} / \mathrm{m} \mathrm{n}$. is insufficient to support life with severe anemia. Some effort has also gone into gathering information concerning variations in daily power profiles and concerning steady state and transient response requirements of the artificial heart. An analysis of this information will be carried out this summer. Contract requirements are being met. The principal investigator has devoted approximately $20 \%$ of his time since the beginning of the current term of the contract and is expected to devote approximately $50 \%$ of his time during the remainder of the contract term. One abstract relating to this contract has been published. F. M. Donovan, Jr. "Cardiac output sufficiency and predicted impairment in the U.S. population using the nuclear powered artificial heart" Amer. Society for Artificial Organs, Abstract, Vol. 3, P. 18, 1974.

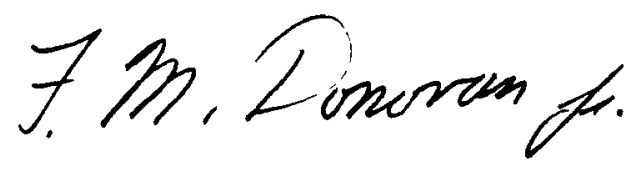




\begin{tabular}{|c|c|c|c|c|c|c|}
\hline \multirow{2}{*}{$\begin{array}{l}\text { Maximum } \\
\text { Artificial } \\
\text { Heart } \\
\text { Output } \\
\text { (1/min) }\end{array}$} & \multirow[b]{2}{*}{ Class } & \multirow{2}{*}{$\begin{array}{l}\text { Maximum } \\
\text { Work } \\
\text { Grade }\end{array}$} & \multirow{2}{*}{$\begin{array}{l}\text { Approximate } \\
\text { Maximum } \\
\text { Sustained } \\
\text { Activity } \\
\text { ( } \mathrm{Kcal} / \mathrm{min}) \\
\end{array}$} & \multicolumn{3}{|c|}{ Percent of Adult U. S. Populati } \\
\hline & & & & $\begin{array}{l}\text { No } \\
\text { Anemia }\end{array}$ & $\begin{array}{l}\text { Moderate } \\
\text { Anemia }\end{array}$ & $\begin{array}{l}\text { Severe } \\
\text { Anemia }\end{array}$ \\
\hline 12 & $\begin{array}{l}\text { N } \\
\text { I } \\
\text { II } \\
\text { III } \\
\text { IV } \\
D\end{array}$ & $\begin{array}{l}\text { Heavy } \\
\text { Moderate } \\
\text { Light } \\
\text { Very Light } \\
\text { None }\end{array}$ & $\begin{array}{l}5.5+ \\
3.0-5.5 \\
1.6=3.0 \\
0.4=1.6 \\
0.0-0.4 \\
\end{array}$ & $\begin{array}{r}13 \\
86 \\
1 \\
0 \\
0 \\
0\end{array}$ & $\begin{array}{r}0 \\
0 \\
58 \\
42 \\
0 \\
0\end{array}$ & $\begin{array}{r}0 \\
0 \\
0 \\
27 \\
72 \\
1\end{array}$ \\
\hline 9 & $\begin{array}{l}\text { N } \\
\text { I } \\
\text { II } \\
\text { III } \\
\text { IV } \\
\text { D }\end{array}$ & $\begin{array}{l}\text { Heavy } \\
\text { Moderate } \\
\text { Light } \\
\text { Very Light } \\
\text { None }\end{array}$ & $\begin{array}{l}5.5+ \\
3.0=5.5 \\
1.6=3.0 \\
0.4=1.6 \\
0.0=0.4 \\
\end{array}$ & $\begin{array}{r}0 \\
13 \\
86 \\
1 \\
0 \\
0\end{array}$ & $\begin{array}{r}0 \\
0 \\
0 \\
29 \\
70 \\
1\end{array}$ & $\begin{array}{r}0 \\
0 \\
0 \\
0 \\
0 \\
100\end{array}$ \\
\hline 6 & $\begin{array}{l}\text { N } \\
\text { I } \\
\text { II } \\
\text { III } \\
\text { IV } \\
\text { D }\end{array}$ & $\begin{array}{l}\text { Heavy } \\
\text { Moderate } \\
\text { Light } \\
\text { Very Light } \\
\text { None }\end{array}$ & $\begin{array}{l}5.5+ \\
3.0=5.5 \\
1.6=3.0 \\
0.4=1.6 \\
0.0=0.4 \\
\end{array}$ & $\begin{array}{r}0 \\
0 \\
0 \\
29 \\
70 \\
1\end{array}$ & $\begin{array}{r}0 \\
0 \\
0 \\
0 \\
0 \\
100\end{array}$ & $\begin{array}{r}0 \\
0 \\
0 \\
0 \\
0 \\
100\end{array}$ \\
\hline
\end{tabular}


1. Total acutal project cost to April 30, 1974 for the current period

2. Estimated total cost for remainder of period

$\$ 4,009.37$

3. Total actual and estimated cost chargeable to AEC for current period

4. Accumulated costs chargeable to AEC

5. Accumulated AEC Support ceiling

6. Total estimated AEC funds remaining under contract which may be used to reduce amount of new funds required from $A E C$.

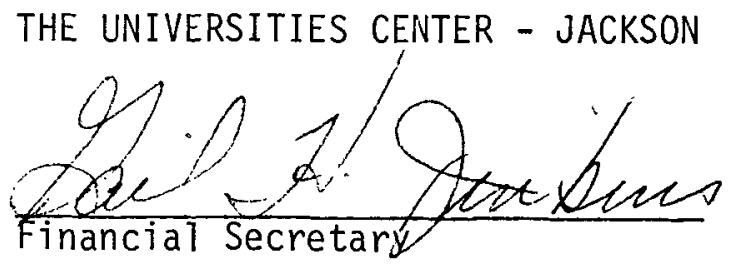

